Part 3, "The Crimean Tatars in the USSR," describes mainly the tragic fate of the Tatars during and after the Second World War. Accused collectively of "treason" and "collaboration" with the Germans, deported in 1943 to Siberia and Central Asia, rehabilitated after Stalin's death-but not allowed to return to their homeland, Crimea, now entirely occupied by Slav settlers-some four hundred thousand Tatars currently live in their places of deportation and are condemned to assimilation by the local population. The pathetic and seemingly hopeless struggle of this small community against the Soviet state is the subject matter of the last chapter of this book, which is based primarily on samizdat material.

Alexandre Bennigsen

Ecole Pratique des Hautes Etudes and University of Chicago

SOVETSKII TATARSTAN: TEORIIA I PRAKTIKA LENINSKOI NATSIONAL'NOI POLITIKI. By Tamurbek Davletshin. London: Our Word Publishers, 1974. 392 pp. Illus. DM 28, paper.

Davletshin's work traces the history of the Volga and Ural Tatars under Russian hegemony from the Muscovite conquest of Kazan' through the February and October Revolutions, the civil war, and the period of Soviet rule. More than one hundred pages are devoted to events of a single year, from the end of tsarist rule to the establishment of the Tatar-Bashkir Soviet Republic in March 1918. Especially detailed is the author's treatment of the First All-Russian Congress of Muslims (held in Moscow, May 1-11, 1917), in which some eight hundred delegates participated. He quotes extensively (in Russian translation, evidently his own) from the protocols of the congress as published in Tatar in Petrograd the same year. Appendixes include translations from Tatar of other documents of the period.

The importance of the national culture in Tatar history is reflected throughout. A separate chapter traces the rise, especially in the nineteenth century, of indigenous education and Islamic reform movements, guided by an intelligentsia deriving its inspiration from both Oriental and Western sources. The last part of the book deals with cultural problems under Soviet rule. Paradoxically, it is perhaps the weakest section, omitting mention of the work of contemporary Tatar authors whose development of nationalistic themes has attracted attention in the West.

Although the author, a Tatar émigré with a background in Soviet law, does not conceal his basic aim of indicting Soviet policies, his book is much more than a propaganda diatribe. It contains a great deal of documentary material, copious footnotes, and a bibliography listing nearly one thousand titles.

James Critchlow

U.S. Board for International Broadcasting

\title{
POLISH REVOLUTIONARY POPULISM: A STUDY IN AGRARIAN SOCIALIST THOUGHT FROM THE 1830s TO THE 1850s. By Peter Brock. Toronto and Buffalo: University of Toronto Press, 1977. viii, 125 pp. $\$ 10.00$.
}

This is the third published collection of Peter Brock's numerous articles and essays on aspects of nineteenth-century Polish intellectual history. The four essays, reprinted here with some stylistic revisions, originally appeared between 1959 and 1961 in Canadian, British, and Italian journals and in the Festschrift for G. D. H. Cole. The notes and bibliography have been updated, and Brock has rearranged portions of the essays to provide a connected account of the varying expressions of Polish revolutionary agrarian socialism-both in West European exile and in the partitioned homeland -in the two decades that followed the suppression of the 1830-31 insurrection. In 